ESJ Social Sciences

\title{
Effects of Divorce in the Happiness of Children
}

\author{
Fabjana Bakiu Maksutaj \\ University of Tirana, Faculty of Social Sciences, Albania
}

\section{Doi:10.19044/esj.2021.v17n35p102}

Submitted: 15 September 2021

Accepted: 29 September 2021

Published: 31 October 2021
Copyright 2021 Author(s)

Under Creative Commons BY-NC-ND

4.0 OPEN ACCESS

Cite As:

Bakiu M. F. (2021). Effects of Divorce in the Happiness of Children. European Scientific Journal, ESJ, 17 (35), 102. https://doi.org/10.19044/esj.2021.v17n35p102

\begin{abstract}
This study investigates the impact that parent's divorce has on the happiness of Albanian children in the city of Tirana. The age group was determined to be from 13 to 18 years old, because it related to adolescence, which is a difficult stage in which the child is prepared for the transition as an adult. The goal is to measure the level of happiness according to the subjective perception of the children for the time when they lived with both parents, and after that of divorce. Its achievement was accomplished by setting of such goals as: was the child happy before the divorce of the parents, is he happy after it now? Is he happy with the life he leads and would he liked to live with both parents again? If yes, what would it change in his life and would his happiness increase? Methodology involves a primary survey with the help of a structured questionnaire among 405 children from 19 public elementary and high schools in Tirana. The consequences of divorce to happiness of children are theoretically explained and give the opportunity to raise research questions in recent years. The research instrument includes questions about the level of happiness before and after parental divorce and the impact of parents relationships after divorce on happiness for this segment of children. The data analyse have led to conclusions and recommendations on social policies to be followed towards this segment in the future.
\end{abstract}

Keywords: Happiness, adolesence, family, subjective wellbeing, coparenting 


\section{Introduction}

"If we have happy children today, we will have a better and healthier society tomorrow ${ }^{l}$ ",

The beginning of this study was born over the great concern of the increased numbers of divorces during the last 30 years in Albania, and on the impact that these divorces have on the happiness of children. As divorce has become a growing trend in Albanian society, increasing not only the number of single-parent families, but also the number of children living in these families, the other concern is about what is the emotional state of these children, and how capable are they of facing this challenge that life has unfairly set before them.

Researchers position themselves in two different directions in terms of the consequences that divorce leaves on children. One group includes those who support the thesis that divorce does not cause great psychological consequences and that it is a necessary evil. The second group of researchers defends the thesis that divorce causes profound psychological consequences for children which will be very crucial in their later adult life and in the decisions they will make during their lives regarding the decision to make sustainable connections, and future family creation.

Studies have shown that: "Family disruption during adolescence does lead to a substantial loss of income for children, regardless of the race and educational background of their parents (McLahanan \& Sandefur 2005, p.86). It is concerning that divorce has begun to have consequences even in the relationships that parents have with their children. The traditional Albanian family, even in the conditions of the divorce, has valued the children more than themselves and in any case has placed them on the personal motives of the couple quarreling, keeping the children away from the conflicts of the marriage and the intimate consequences of the divorce (Tushi, 2012).

Munevver Mertoğlu in his study of 2020 about "Factors Affecting Happiness of School Children" confirms that "The happiness level of students whose parents are not divorced $(3,20)$ is higher than the that of students whose parents are divorced (3.03)" (p.18). Also "Students whose parents are not getting along well and divorced are less happy than the students whose parents are getting along well and together is an important finding as rates of divorce has increased rapidly compared to previous years" (p.19). "When parents divorce each other, another sort of divorce occurs between the parents and their children. The primary effect of divorce (and of the parental conflict that precedes the divorce) is a decline in the relationship between parent and child" (Cited in. Fagan \& Churchill, 2012, p.3).

\footnotetext{
${ }^{1}$ Author's note.
} 
Also, "Single parenthood reduces children's chances in at least two ways: by lowering their aptitude for school and by lowering their motivation as well (Mc.Lahanan \& Sandefur 2005, p.46)“.

\subsection{Why is Happiness so Important, Especially for Children?}

Happiness is one of the main goals in human life, for having the best quality of life and the best possible well-being. For adults, who are able to act, this concept is more aware and aims to be achieved more often and more powerfully, while for children it depends mainly on the adults who take care of them, and other circumstances of course. This is why it is very important to pay special attention to the happiness of children because if we raise happy children today we will have a better and healthier society tomorrow. But children cannot do it alone without the help of adults and without the help of institutions.

\subsection{Concepts of Happiness}

Dan Haybron in his article about "Happiness" states: "There are roughly two philosophical literature on "happiness," each corresponding to a different sense of the term. One uses 'happiness' as a value term, roughly synonymous with well-being or flourishing. The other body of work uses the word as a purely descriptive psychological term, akin to 'depression' or 'tranquility'(Haybron, 2020).

Most empirical studies suggest that happiness is a predictor of psychological, social and personal well-being and happiness is a subjective experience related to positive feelings across the life span and different cultures.“(Verrastro, Ritella, Saledino, Pistella, Baiocco \& Fontanesi L. 2020)

"Overall happiness is the degree to which an individual judges the overall quality of his/her own life-as-a-whole favorably. In other words: how much one likes the life one leads" (Veenhoven, 2012, p.5). ( This definition is explained in more detail in Veenhoven (1984:22-25) (cited in Veenhoven. P.5.)

Furthermore, the family structure can constrain family availability to provide its functions related to the social, human, and time resources they devote to children for assuring their well-being. (Dervishi, Sado, 2013, page 377).

\section{Purpose and Objectives of the Study}

The purpose of this study is to measure the level of happiness in children of age 13-18 years, with divorced parents, before and after parents' marriage dissolution. It aims to answer specific questions like the following, in order to obtain a concrete result of the emotional situation in which the children are living. 
- Who do you live with?

- Does your father work?

- Does your mother work?

- Does the noncustodial parent pay the economic obligation set by the court?

- How difficult is it for you to live with only one of your parents?

- Would you like your parents were not divorced?

- Would you like to live with both parents?

- Why would you like to live with both parents?

- Did you feel happy when living with both parents?

- Are you happy now?

\section{Methodology}

Subjective perception of happiness was used in this study. Positive psychology studies have found that happiness, and its pursuit during one's lifetime, is an indicator of personal satisfaction and subjective wellbeing (Donaldson et al., 2015; Parks et al., 2012), (Cited in. Verrastro et.al, 2020 ). Its level is determined by children's perceptions of happiness, based on their emotional state over the experience of parental divorce. The participants are children of divorced parents, between 13-18 years of age in public schools in Tirana. The sample was made up of 19 public schools which were identified to have the highest number of children with divorced parents, 9 of which were elementary, and the rest were high schools. 500 questionnaires were distributed, of which 405 questionnaires were answered and returned.

\section{4. $\quad$ Findings}

Demographic Information: Of the 405 respondents, $60.49 \%$ of the population were females and $39.51 \%$ were males. $77.23 \%$ of children lived with their mother, and 14.11 lived with their father, 6.93 lived with the mother's family and $1.73 \%$ lived with the father's family. $74 \%$ of the mothers were employed versus $26 \%$ of them who were unemployed, compared to $80.38 \%$ of the fathers who were employed, versus 19.62 of them who were unemployed. Even most of the fathers are employed, 51,85\% of the children confirmed that the non-custodial parent never pays the financial obligation and only $16,3 \%$ of them contribute every day financially. Meanwhile, 3,7\% pay it once a month and 2,47 \% pay it more than once a month. Only 23,7 contribute once a week and $1.98 \%$ of the children did not answer this question. In general, it means that more than half of the divorced children and their family members suffer lower economic income compared with those before the divorce. 


\section{Happiness of the Children Before and After the Divorce of the Parents}

In general the data show that the happiness of children decreases after the parents" divorce. For the part of the children who "feel always happy", it turns out that their number has decreased after their parent's marriage dissolution.

Also, the data show that there is a relatively high percentage of children who have never felt happy, even when they lived with both parents, and after their divorce too. This percentage turns out to have increased and this high number of unhappy children is due to the existence of a high level of conflict in the Albanian families which go through a divorce. This conflict is present before marriage dissolution and still continues to be after divorce, which affects the inner world, the peace of mind, and the hearts of children by making their experience a childhood, unlike other peers.

Happiness Before Divorce: Children were asked if they were happy when they lived with both parents. 39.35\% of them confirmed that they never felt happy, or felt happy sometimes when they lived with both parents, versus $60.64 \%$ of the total who felt always happy or felt happy most of the time.

Happiness After Divorce: When children were asked if they were happy now (living with one of the parents), they answered: $44.76 \%$, of them, never feel happy, feel happy a few times or feel happy sometimes, comparing to $55.78 \%$ of them who confirmed that they feel always happy or most of the time.

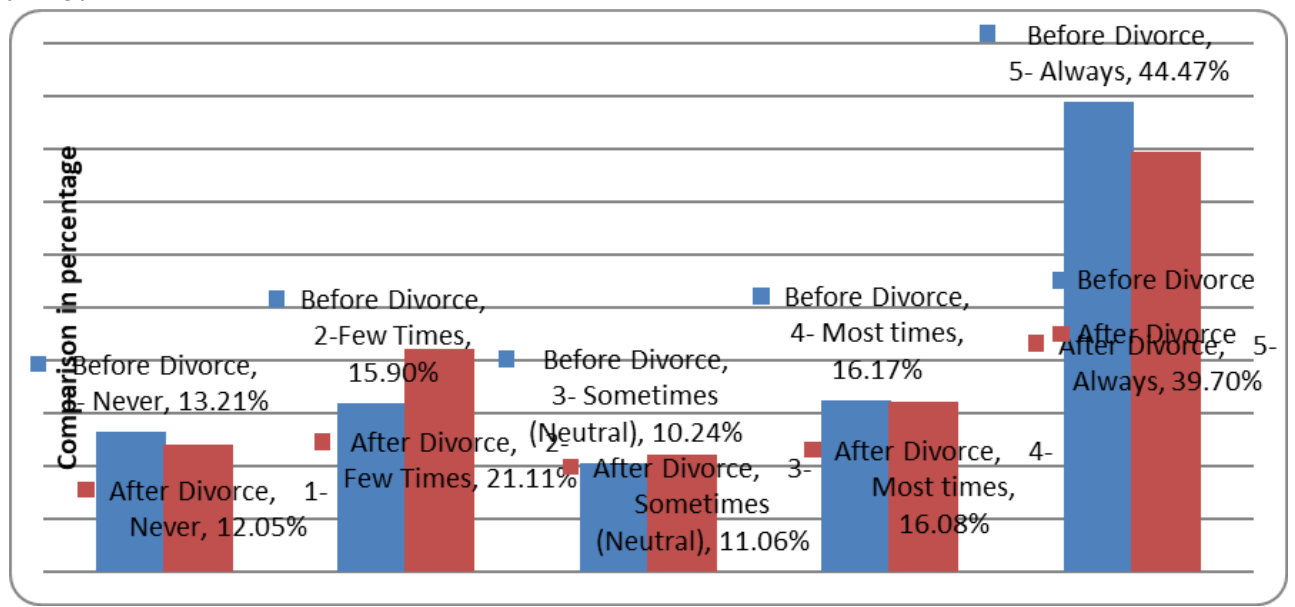

Table 1. Level of Happiness Before and After Divorce

\section{The difficulty of Living with One of the Parents}

When children were asked if they found it difficult to live with only one parent, they answered: $27.23 \%$ of them find it difficult, very difficult, or extremely difficult. Translated into numbers, it means that 110 children of the whole sample, face great difficulties in living with one of the parents. This number is considerable and needs urgent attention from both parents, in order 
to better co-parent and improve their children's lives in this regard. Meanwhile, $40.59 \%$ of them answered it was not difficult at all and $32.18 \%$ said this is neither easy nor difficult.

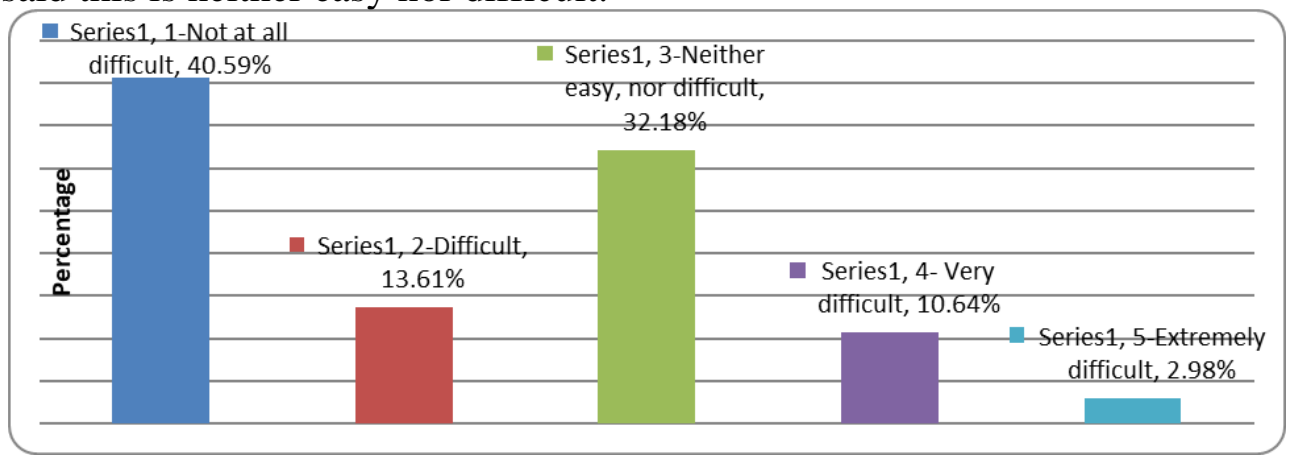

Table 2. Difficulty of living with only one parent

\section{Children's Wish that Their Parents Were not Divorced}

When children were asked if they wanted their parents were not divorced, most of them, $88.51 \%$ answered they wished their parents were not divorced and the rest, $19.14 \%$ agreed with their divorce.

\section{The Children Were Asked if They Would Like to Live With Both Parents}

Most of them $44.59 \%$, answered they would always like to live with both parents, while 20.15 said they would never want to live with them both. $17.88 \%$ of children think sometimes about living with them, and $17.38 \%$ of children think of this many times or most of the time.

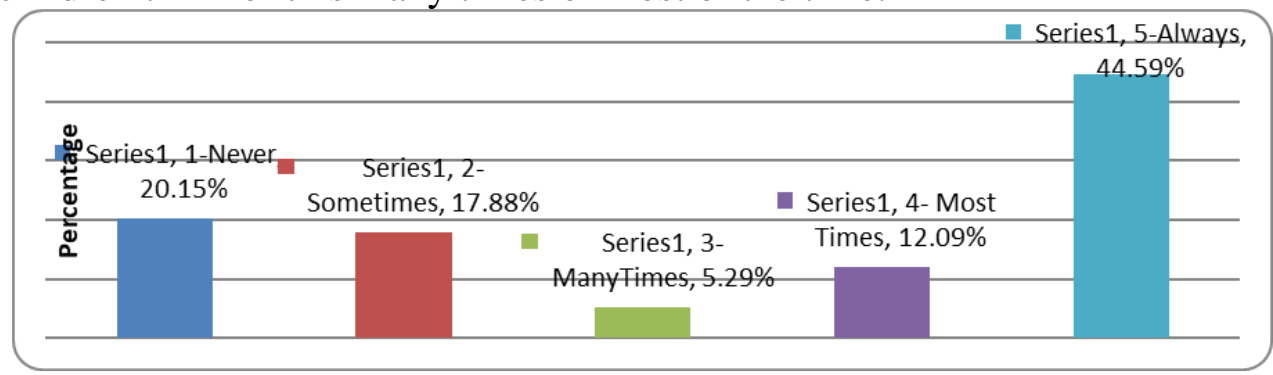

Table 3. Children's desire to live with both parents

\section{The Reasons Why the Children Would Like to Live with Both Parents}

When children were asked this question, most of them 37.2\%, answered that they would feel more spiritually calm if they lived with both parents, followed by $28.1 \%$ who said that their life would be better, more beautiful, and calmer. $22.21 \%$ of them said they would be happy with both parents, followed by $7.26 \%$ who have accepted that they would have better economic opportunities and $5.23 \%$ would attend the school or activity they wanted. 


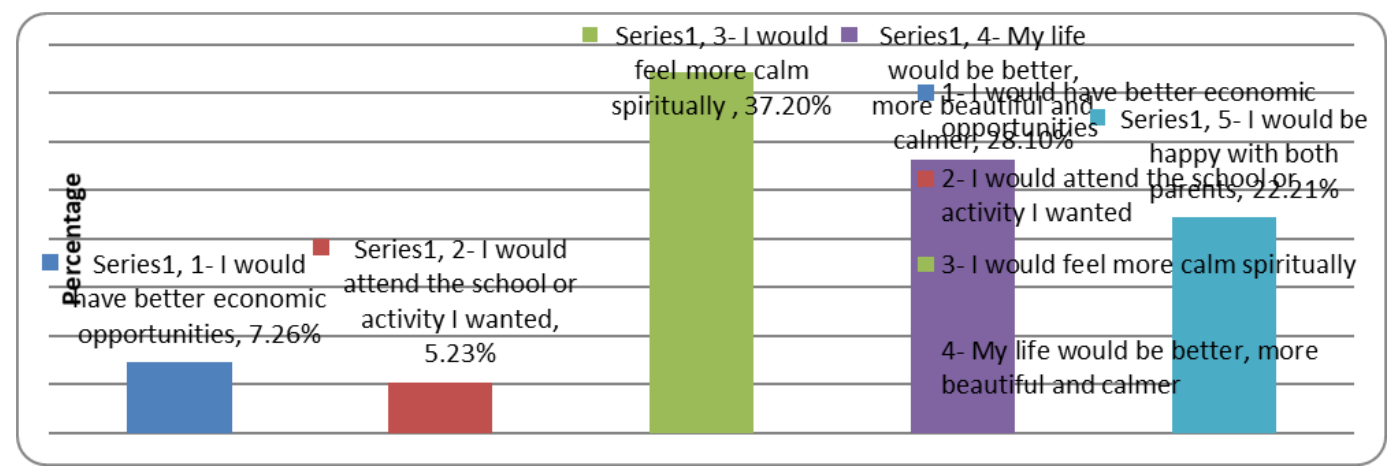

Table 4. The Reasons the Child likes to Live with Both Parents

\section{Which is the Relationship Between Your Parents?}

Although divorce has occurred and sposes live no longer together, it turns to be that $44.7 \%$ of them continue to have bad or very bad relationships with each other, and only 22.6 have positive or very positive relationships. The number of parents that do not have good relationships is considerable and affects the level of happiness of their children by lowering it compared to the level before the divorce. A study, taken in Albanian court in 2012 by Valbona Treska, confirmed this too: " $69.2 \%$ of divorce petitions qualify as a conflicting or violent divorce where in addition to spouses in the process, the conflict also generates in the child / s or environments family of each of the spouses" (p.591).

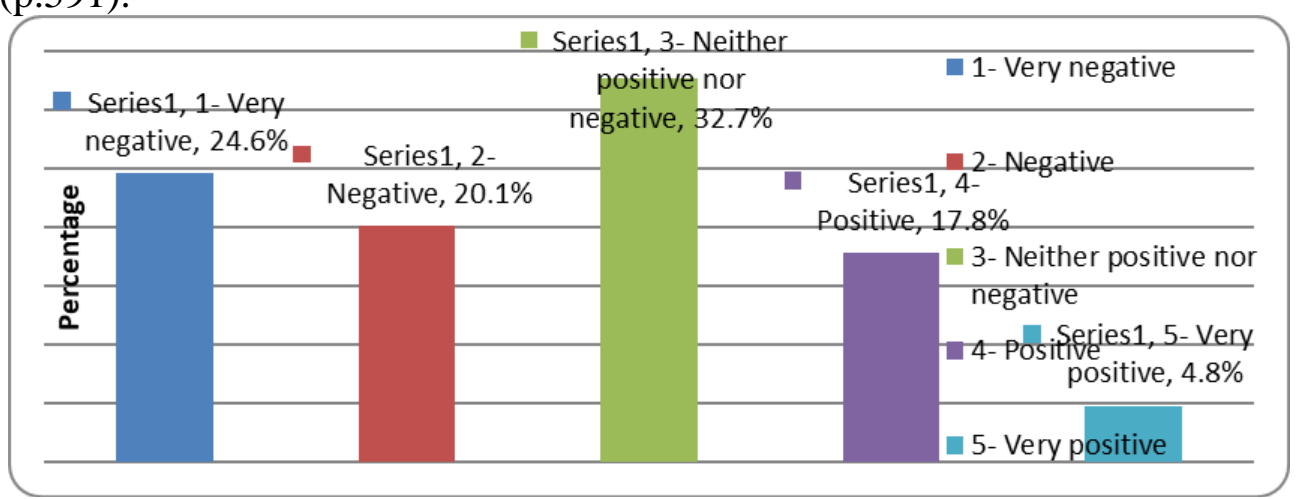

Table 5. Relationships between divorced parents

\section{Conclusion}

This study aimed to determine the level of happiness in children aged 13-18 years and found that their happiness, in general, has decreased after parental divorce. Most of the children who took part in the study would liked their parents were not divorced. If this could happen, they would feel calmer and their life would be more beautiful, and they would feel better and happier. In general, more than half of the divorced children and their family members suffer lower economic income compared with that before divorce, but only a 
small number of children are interested in having better economic opportunities or having the education they want. This is a significant fact, which tells us that the lives of children with divorced parents are troubled and that there is a lack of peace in their minds and souls. In a few words, they are not worried about the economic situation, before the spiritual one.

The study revealed that a quarter of children are unhappy, both before and after parental divorce. This number is related to the conflicting relations of the spouses that existed between them before they broke up and went to divorce, but that still continue to be conflicting even after they divorced.

\section{Recommendations}

It is clear that children, parents, and society as a whole will have longterm consequences due to divorce. But the most important in this study was the happiness of children which has a great cost to their quality of life. Therefore, it is very important to pay attention to their well-being and happiness in the long run, by all, parents, family members, friends, teachers, and of course the state.

Parents, in particular, should take special care to maintain a good relationship with each other in order to co-parent as best as possible, even after their divorce, making the child feel the warmth of a family in order to not feel abandoned or marginalized. The non-custodial parent should not only meet their children more often, but these meetings should be qualitative in order to increase the attachment between parent and child relationship.

For those couples who have less serious disagreements such as violence, gambling or alcoholism, family and mutual friends should play a major role in advising each spouse, not to end the marriage, but to try to fix their problems and improve their relationship, in order to not go to divorce. If it were possible, why not reunite and try again from the beginning. If love once existed between them, it can always exist. This is a hope for all those children whose parents have problems and see divorce as the one solution. The children of these families deserve a better and more qualitative life, without the worry of divorce inside their mind and soul. Teachers should also pay attention to this category of children in their daily life to support and encourage them in the learning process, but also beyond it, so that the child does not feel excluded from the rest of the peers.

The state should provide better services for families applying for a divorce. Courts, but not only, must provide counseling services, more than once, for the salvation of the family and for the benefit of all its members, especially children, who suffer the consequences of separation more than all. Also, school psychologists should provide counseling services for children whose parents are in the process of divorce or who are already divorced, in order to support them how to cope with it, without injury and suffering. They 
should prepare them to become psychologically healthy adults and hopeful for a better future than that of their parents.

\section{References:}

1. Rodríguez-Pose, A \& Von Berlepsch,V. (2012). Social Capital and Individual Happiness in Europe, College of Europe, Department of European Economic Studies, Bruges European Economic Research Papers, file:///C:/Users/BiNKA/Downloads/beer25.pdf

2. Dan. H "Happiness", The Stanford Encyclopedia of Philosophy (Summer 2020 Edition), Edward N. Zalta (ed.), URL = https://plato.stanford.edu/archives/sum2020/entries/happiness/ This entry was first published on Wed Jul 6, 2011. It was last modified on May 28, 2020.

3. McLahanan, S. \& Sandefur, G. (2005). Growing Up with a Single Parent, Harvard University Press, Cambridge Massachusetts, London England.

4. Mertoğlu, M. (2020). Factors Affecting Happiness of School Children, Journal of Education and Training Studies, Vol. 8, No. 3, p.; March 2020, doi:10.11114/jets.v8i3.4674

5. Neufeld, G. \& Mate, G. (2006). Hold on to your Kids, Ballantine Books

6. Wolfinger, N. (2005). Understanding the Divorce Cycle, The Children of Divorce in their own Marriages, (C) Cambridge University Press.

7. Fagan. P, \& Churchill, A. (2012). The Effects of Divorce on Children https://downloads.frc.org/EF/EF12A22.pdf ).

8. Veenhoven, R. (2012), Happiness: Also known as "life-satisfaction" and "subjective well-being":

https://www.researchgate.net/publication/278665173

9. Treska.V. 2012, Divorce Trends And Their Psychological Causes in Albanian Couples, Journal of Institute Alb-Shkenca, Copyright (C) Institute Alb-Shkenca, https://www.apa.org/pi/families/resources/develop.pdf

10. Verrastro, V. Ritella, G. Saledino, V. Pistella, J. Baiocco, R \& Fontanesi, L. (2020). Personal and Family Correlates to Happiness amongst Italian Children and Pre-adolescents, International Journal of Emotional Education, Volume 12, Number 1, April 2020, pp.48-64

11. Wallerstein, J. S. Lewis, J.M \& Blakeslee, S. (2000). The Unexpected Legacy of Divorce, The 25 year Lendmark Study, (c) Library of congress, Cataloging -in-Publication Data).

12. Dervishi, Z. Sado, L. Spaho, A. (2013). Family Structure and Functioning and the Implications for ChildWell-being in Albania, Academic Journal of Interdisciplinary Studies, MCSER PublishingRome, Italy, Vol. 2, No. 9 October 2013. 